Participation, empowerment and capacity building: Exploring young people's perspectives on the services provided to them by a grassroots NGO in sub-Saharan Africa

Morgan, JE

http://hdl.handle.net/10026.1/4965

10.1016/j.childyouth.2016.04.012

Children and Youth Services Review

All content in PEARL is protected by copyright law. Author manuscripts are made available in accordance with publisher policies. Please cite only the published version using the details provided on the item record or document. In the absence of an open licence (e.g. Creative Commons), permissions for further reuse of content should be sought from the publisher or author. 


\title{
Participation, Empowerment and Capacity Building: Exploring young people's perspectives on the services provided to them by a grassroots NGO in sub-Saharan
}

Africa

\begin{abstract}
$\underline{\text { Abstract }}$
This paper explores young people's perspectives on the services that were provided to them by one NGO in sub-Saharan Africa. Semi-structured interviews and discussion groups were carried out with 71 young people, aged between 10-18 years old, who lived and worked on the street. Volunteer facilitators $(n=26)$ who run the groups and who had either previously lived on their street themselves or who lived in the 'informal slum areas' also took part in the discussions. A number of challenges and tensions became apparent from discussions including issues around capacity building, empowerment, participation and the depoliticised nature of social action.
\end{abstract}

Keywords: 'Street children'; informal slums; sub-Saharan Africa; children and young people's perspectives; participation; empowerment, capacity building; evaluating services

\section{NGOs and International Development}

Non-Government Organisations (NGOs), defined as 'self-governing, not-for-profit organizations that are geared to improving the quality of life of disadvantaged people' (Vakil 1997:2060), have over the last three decades or so, become powerful players in international development. NGOs are seen to have an important role to play in service delivery, advocacy, and capacity building of individuals and communities and are held up as being well positioned to offer innovative and flexible services which are grassroots and respond to local need (Coates and David 2002; Brown \& Korten 1989). Moreover, as part of civil society, NGOs are thought to have an important part to play in ensuring that the voices of the 'poor' and 'disadvantaged' are heard at policy level and that governments are held to account for their policies and the provision of 'pro-poor' services (Brown \& Korten 1989; Chambers 1997). 
However, there are numerous difficulties that arise around the role of NGOs in international development. One source of conflict concerns funding and how donor requirements may undermine the ethos and mission of NGOs as well as lead to a reduction in innovation and diversity across the NGO landscape. Furthermore, a lack of funding can result in the work of NGOs becoming 'funding led' with the value base of the donor organisation often dominating the relationship (Wallace \& Mordaunt 2007; Chambers 2005). This is seen as potentially problematic as many donors, based in Northern countries, may have particular visions of what needs to be the focus of development initiatives and hence services provided in countries in the Global South, for example, may be influenced more by international dictates than local need. A power dimension exists, therefore, between donors and recipients of funding and this can be magnified when the government of the country is the donor of funding, for example through direct budgetary assistance; compromising the ability of NGOs to hold governments to account or be critical of their policies.

\section{Participation, Empowerment and Capacity Building}

One of the important roles ascribed to NGOs is that of empowering local communities through the use of people centred participatory processes as well as through building the capacity of local people. The participation of stakeholders, including local people, in the design and running of projects is seen as important by many in international development because client participation is said to result in projects that meet local needs, are more sustainable and thus more effective (Johnson and Wilson 2000). Moreover, grassroots participation is held to be about social justice and emancipation bringing about empowerment or 'conscientization' (Freire 1970). Thus, participation is viewed by many as a political act which supports the 'vulnerable' or 'poor' in taking charge of their own destinies with the end result being the transformation of society (Chambers 1997; Fals Borda \& Rahman 1991; Freire 1970). However, participation as a concept can be problematic and very often the political nature of participation can be down-played. Cornwall (2002; 2003) highlights this by distinguishing between invited and claimed spaces of participation. Cornwall argues that the former (invited) are more formal events where development agencies create forums for stakeholders to contribute, have their voices heard and reach consensus. However, these invited spaces for participation, which are very popular with development agencies, do not necessarily result in political transformation of the way that society operates. Claimed participation, however, according to Cornwall, is more organic 
and involves the poor taking control of the political processes without necessarily being invited in and equates more to Freire's notion of participation. Parfitt (2004) argues something similar with the distinction between 'participation as an end' (for example participation in the way envisaged by Freire and claimed participation as envisaged by Cornwall) and 'participation as a means' (for example as an apolitical way to improve service delivery through listening to the voices of service users).

How participation is thought about, therefore, by NGOs and by development agencies can impact on the type of social action that occurs. For example, a common critique of many participatory projects is that they can maintain the status quo and are used to support dominant ideas of development which are influenced by neo-liberalism, citizenship and free trade as opposed to responding to local need (Cooke 2004; Laverack and Wallerstein 2001; Cooke and Kothari 2000). Invited participation or 'participation as a means', therefore, may be used to mask power dynamics which ensure that those with the most power have the most say (Mosse 1994). This can, in turn, further disempower the most vulnerable by giving the impression that their voice is being listened to whilst in reality what is taking place is a form of tokenistic participation which is supportive of the agendas of the more powerful (Arnstein 1969).

Empowerment of local people is often held up as one of the goals of many development agencies and NGOs, but the term empowerment is, like participation, problematic. An important aspect of the term empowerment is the word power and this is often not reflected upon by development agencies. Rowlands (1995), as well as Mayoux and Johnson (2007), outline four types of power relations: power within (relates to self-worth and is according to Mayoux and Johnson also about 'giving voice'), power to (an individual's ability to act including increasing capacity, knowledge and skills), power with (collective action) and power over (obedience or force). Mayoux and Johnson (2007:183) also highlight how development agencies can challenge 'power over' by focusing on 'changing attitudes and behaviours of the powerful and changing discriminatory and unequal institutional structures and policies'. It is not always clear, however, given the different types of power relations which exist, what it means to be empowered and single strategies for empowerment, therefore, can be problematic given the complexity of power (Mayoux \& Johnson 2007). Questions arise, therefore, as to what the role of development agencies are in relation to empowerment. As Mayoux \& Johnson (2007) suggest is it about increasing voice and 
capacities (invited participation or participation as a means or power within) or is to confront and transform power relations which maintain the status quo and disadvantages some groups; or is it a combination of the two? What form, therefore, should empowerment take and what is the aim of empowerment? Supporting peoples voices being heard without really doing something about the status quo which positions people in subordinate roles is highly problematic and a common critique of many empowerment projects is how much structural change has actually occurred and how far empowerment of groups has any longer term impact on how things are done politically and socially (Laverack and Wallerstein 2001).

Moreover, Pettit (2012) shows how power can be both visible and formal (i.e. power relations between people or organisations or laws and rules which define what is acceptable) or invisible or informal power (norms and beliefs and values which are part of everyday life the discourses that no-one questions). Empowerment which focuses only on visible forms of power and does not tackle invisible forms of power can also be problematic and can lead to the position of poor children, who live on the street, not being questioned. Furthermore, Rowlands (1995) talks about how 'power over' can become internalised by those who are oppressed so that they themselves do not question their situation nor do they question how they are represented.

However, politically empowering 'vulnerable' groups, especially children who may challenge norms of what children should be like, is not without its own tensions and issues and may result in these groups being at increased risk of aggressive behaviour from those in powerful positions or from authoritarian governments. Moreover, questioning mainstream development approaches and power relations too much can also lead to difficulties for NGOs. As Pettit states (2012 p7) 'a major obstacle to achieving liberating empowerment is that institutional drivers will often determine the approaches that are favoured and rewarded'. Those NGOs, for example, who question too much or who are too radical may be ostracised by losing funding.

Capacity building or capacity development has been defined in a number of ways. One definition is the

'process whereby individuals, groups, and organisations enhance their abilities to mobilize and use resources in order to achieve their objectives on a sustainable basis. 
Efforts to strengthen abilities of individuals, groups, and organisations can comprise a combination of (i) human skills development; (ii) changes in organisations and networks; and (iii) changes in governance/institutional context' (ADB 2004 cited in DFID 2008).

Capacity building, however, is often understood in relation to human skills development per se and the premise that by participating in initiatives or interventions individuals and groups will learn new skills, attitudes and knowledge which will increase their human and social capital; making it more likely they are able to be agentic actors who are able to bring about sustainable change in their lives. This can be, in part, related to Sen's idea of 'freedom' and his focus on human development and of strengthening human capabilities (2001). However, Sen's work on capability (and the definition above) goes further and Sen shows that without opportunities, for example jobs, capacity building programmes which focus on new knowledge and skills will not be enough to improve well-being. Instead reflection on the opportunities which are available to individuals and groups is needed to uncover structural processes and power relations which may disadvantage some groups and stop them realising their capabilities.

There are many tensions, therefore around the concepts of participation, empowerment and capacity building and this can result in the rhetoric not always matching the practice (Chambers \& Pettit 2004) with the rhetoric being "little more than fashionable labels attached to the same underlying systems" (Chambers \& Pettit 2004: 138). This is a point also made by Oxaal \& Baden (1997: 24) who state that many "agencies run the risk of merely renaming top-down approaches as part of an empowerment policy". This can result in a depoliticised system where participation, empowerment and capacity building does not bring about structural change or social transformation but is rather about enabling the 'poor' and 'vulnerable' to have their voices heard in relation to agendas that are set by more powerful players (Freire 1970; Fals Borda \& Rahman 1991; Cornwall \& Brock 2005). Moreover, this type of system can limit and constrain the ability of NGOs to advocate and be political on behalf of the groups that they represent in case this 'upsets' agendas which have already been set; this can result in NGOs having 'thin agency' (Klocker 2007). 
Children and young people who live and work on the street or 'street children', as they are commonly known, are a marginalised, socially excluded, group of children and young people who face a range of risk factors including discrimination, violence and abuse (Thomas de Benitez 2011). They are often faced with a lack of access to services and yet are at high risk of a number of poor outcomes including sexual and reproductive health issues, poor nutrition, substance and alcohol abuse, poor mental health and increased risk of physical injuries (World Health Organisation 2000; Ennew 2000). Services for 'street children' can take many forms including street outreach programmes; services which aim to reintegrate the young people back into their families; initiatives which work with families to improve the conditions at home; preventative programmes within communities at increased risk of children coming to the street; education programmes which focus on risk factors including drug use and HIV/Aids; skills training, schooling and education programmes; drop-in centres which provide food and shelter; institutional care; advocacy work, and the use of activities such as sport, theatre and art (Dybicz 2005; Berckmans et al 2012). Many of these services are provided by grassroots NGOs but funded by governments, international NGOs and other bi-lateral and multi-lateral funders. A focus on empowerment, participation and capacity building is often at the heart of many services offered by NGOs to 'street children'.

The provision of services to 'street children' may be underpinned by many types of discourse which can include some or all of the following (Thomas de Benitez 2003; Rizzini \& Lusk 1995). First, services can be informed by discourses which view the children and young people 'as risk'. This type of discourse may represent 'street children' as out of control drugtaking delinquents who are sexually active; immoral; criminally inclined; aggressive and lacking in respect for the social order (Bleazley 2003; Berckmans et al 2012). Instead of behaving like children they are viewed as behaving like adults; and this transgression often results in them being dealt with punitively and brutally by some adults including those who are meant to protect them (Sondhi-Garg 2004). Services which are informed by this type of discourse may focus more on forcibly changing individual behaviour through institutional care and the situation that the child finds themselves in may be seen as a personal failure (Berckmans et al 2012). Second, services may be informed by discourses which position the children and young people as 'at risk'. The children or young people may be viewed as victims who are homeless, exploited and abandoned by parents and thus at risk of a number 
of poor outcomes. The street, in this type of discourse, is seen as a dangerous place that is not child-friendly and is viewed in opposition to the home where children 'belong' (Ennew 1995). As a result, these children like a range of other children who are said to be streetconnected or 'on the move' are 'out of place' and are in need of saving and protection (Berckmans et al 2012). Services which are informed by this type of discourse tend to focus on the provision of shelter, food and safety as well as emphasising the importance of reintegration into their families and communities. Third, is a viewpoint that emphases the role of structural inequalities in creating the circumstances which lead children and young people to live and work on the street. Services, which are influenced by this type of discourse are said to focus on empowerment and education as a way to offer children and young people positive mechanisms to deal resourcefully with the very difficult situations and hostile environments that they face. Moreover, these services may aim to bring about some form of structural change or social transformation through advocacy work and empowerment strategies working with young people to raise awareness and highlight the 'unfair' situations that they are in. Prevention strategies using community development to strength families and communities with the aim of stopping children from coming to the street in the first place may also be evident (Lusk 1989; Carrizosa \& Poertner 1992; Rizzini \& Lusk 1995; Dybicz 2005; Berckmans et al 2012). However, it is interesting to note that empowering children to become active agents can be viewed as problematic by some and Bordonaro (2012:414) shows how in Cape Verde street children's agency was seen as 'forms of deviance that needed to be corrected by an educational programme'.

Although, there are numerous academic articles documenting the impacts, normally negative, of living on the street on children and young people as well as a large body of literature which explores the difficulties in defining who is or who is not a street child (Panter-Brick, 2002; Ennew, 1986) there are very few journal articles in which children, who live or work on the street, are asked their opinion about the services which they are provided with (Bademci \& Figen 2013). The research that does exist points to the importance of the following: first that services are provided in a loving and caring manner and include the provision of food, shelter, medicine and washing facilities (Southern \& Pralhad 2003); second, the importance of services being like family and offering a secure base (Harris et al., 2011; Kaime-Atterhög et al., 2007); third, that services should focus on the interests of the children (Tjahjorini 2005); fourth that services are flexible and provide learning and training as well as work opportunities (Southern \& Pralhad 2003 ); lastly that schooling and 
education is more responsive to the needs of 'street children' in terms of when children are able to attend (for example, which school shift - morning or afternoon) and financial help in terms of paying for materials and uniform (Salo 2009). Southern \& Pralhad (2003) also identify how the children in their research project highlighted that how they were viewed by society, for example as deviant and being of less worth, impacted on their self- esteem and their future life chances. However, it was not discussed whether the NGOs involved supported the children in this area and one of the recommendations from the report was that organisations should work, with children, to challenges these stereotypes.

The research discussed in this paper aims to add to this knowledge base by exploring the views of children and young people about the services provided by one NGO in one country in sub-Saharan Africa. Understanding children's views is important and underpinned by rights based initiatives such as those informed by the United Nations Convention on the Rights of the Child (UNCRC) (UN 1989) as well as theoretical standpoints which position children as active knowledgeable social actors who have much to say about the world they live in (James \& Prout 1990; James et al 1998; Holloway \& Valentine 2000). By viewing children as having important insights into the world in which they live because of their 'insider' position (Balen et al 2006; Percy-Smith \& Thomas 2010) it is hoped that this will lead to richer understandings of children's worlds, their childhoods, what matters to them and their needs (Hardman 1973). Moreover, understanding how services are experienced by beneficiaries is important because the findings can challenge service providers [and development agencies] to reflect more critically upon how far they are contributing, through their services, to improvements in the lives of 'vulnerable' children. This includes reflection upon taken for granted discourses such as participation, capacity building, power and empowerment which are, as stated above, often highlighted as key areas of many NGOs work with 'street children'.

\section{Method}

This project was a qualitative study focusing on understanding the perspectives of children and young people about the services offered by one NGO in sub-Saharan Africa to children and young people who lived or worked on the street (Christensen \& James 2008; Boyden \& Ennew 1997). The data which is used in this paper was part of a larger evaluation, undertaken by the author, at the request of the NGO to identify ways in which they could 
improve the services that they offered and to enable them to reflect upon their practice and how far they as an organisation improved outcomes for 'vulnerable' children. Reflection is an important tool in development and is defined as 'critical self-awareness of one's predispositions, relationships and interests in the formation of knowledge' (Chambers 2005: xii). Reflecting on action and learning from practical experience requires a focus on being critical about what you are doing and why you are doing it and whether the 'best outcomes' that are promoted are in fact the best outcomes for beneficiaries.

Reference will be made throughout this paper to sub-Saharan Africa as opposed to the country in which the NGO worked to protect the identity of the NGO as identification of the country or area may compromise anonymity. The NGO was a grassroots organisation, run by local people, whose aim was to provide educational messages, share knowledge and empower young people who lived and worked on the street. This was achieved through the use of workshops, the use of theatre, sport, dance and art as well as outreach. Facilitators, who themselves had either lived on the street or who lived in the informal settlements, townships or compounds run a number of groups and provided the outreach; the facilitators were young men and women under the age of 23 years old. The local informal settlements, which the facilitators came from, were areas of entrenched poverty and average life expectancy in these settlements was between 32 - 37 years. Whilst, the facilitators were volunteers and were not paid for their role within the NGO, there were a small number of paid part-time staff who run the office. The NGO had a range of funders including a large international NGO and bilateral donors but a large percentage of their funding came from donations mainly from abroad.

The fieldwork, for this research, took place in 2012 and 2013 and interviews were carried out in a number of places including the NGOs offices, the market place, the street, a restaurant, drop-in centres for street-children, the offices of funders and by Skype. Desk-top analysis of the NGOs documentation, annual reports and records was also undertaken. Semistructured interviews and small scale discussion groups were undertaken with children and young people, aged 10-18, who lived on the street $(n=71)$ as well as volunteer facilitators $(n=26)$ who run the groups. The children and young people who took part in the discussion were primarily male (84\%). A trusted interpreter, who was known to the children, was used in the interviews and the children agreed the choice of interpreter before the interviews took 
place. Funders, other stakeholders and staff from the NGO were also interviewed $(n=12)$ to provide background context and to offer their perspectives on the services provided.

\section{Ethical considerations}

Ethical approval was sought from the University Ethics Committee in the United Kingdom and local child protection policies from the non-government organisation (NGO) were followed. The study was explained to all participants and children were recruited into the study in a number of ways. Children who used the services of the NGO and lived on the street were approached by the researcher and the interpreter and the study explained to them. Where parents were known and accessible, the study was discussed with the parents and consent to approach their child to ask them to take part in the study was gained (Morrow 2009). If children, agreed to take part it was explained to the children that we (the researcher and interpreter) would be in a particular place at a particular time and they could come along to talk. All young people were informed that they could also contact the outreach workers if they wanted to take part and their message would be passed on to us. Children who attended a number of drop in centres were also approached to take part in the research as they also used the NGOs services. It was explained to all children and young people that they did not have to take part in the interviews or discussion groups if they did want to and they could withdraw their consent to take part at any time throughout the interview. This right was exercised by a few children who removed themselves from the area or went to sleep during the discussion. Interviews and discussions were not tape-recorded because of the general noise in the areas where the interviews were carried out and because some children, in the discussions, did not want to be tape-recorded. Extensive notes were taken by the researcher and at the end of each session the young people were asked to highlight what they felt were the main points that they wanted to raise. Children and young people were reminded of the confidential nature of the discussions and that they could also talk to the researcher privately. Some children took up this offer at a later stage. Facilitators were interviewed in groups or on their own dependent upon their choice; again the confidential nature of the discussion was stressed. 


\section{Findings and Discussion}

Thematic data analysis was used to analyse all interviews and discussions and, in all, five key areas were identified by the author who read and re-read all interview scripts highlighting general themes. The themes, therefore, emerged inductively from the data as common across all interviews (Silverman 2006). However, as in all research the themes identified can be influenced by a range of social influences including the positionality of the researcher; an educated, white, western female. If the children and young people, themselves, had analysed the data alternative themes may have been identified as different people have multiple, differing perspectives on the same phenomena. Hence, this paper focuses on the researcher's interpretation of what the children and young people who took part in this research said about the services which were offered to them.

\section{Taking part in the activities: fun, educational and empowering?}

Children and young people (hereafter referred to as young people) were positive about the activities that were provided by the NGO. The activities were described as 'fun', 'entertaining' and 'worthwhile' and the young people spoke enthusiastically about how they had also learnt new practical skills such as acrobatics, acting, dancing, sculpture, singing, poetry and drumming which kept them busy and focused:

'[the activities] keeps me busy....takes my mind of things..... f forget bad things when I am with them'.

Young people also spoke about how they took part in 'workshops', which disseminated information and important public health knowledge and learning about diseases, STI's, HIV/AIDS, safe sex, needle and sharps safety, pollution and climate change. This information was in turn, passed on to others by the young people through community drama productions:

'Through learning, we sit, we learn about dance and learn about issues and skills and pass them on. We learn the skills and pass them on...it is very important'. 
Many of the young people appeared to take pride in what they were taught and especially their role in passing on information to others. However, there was very little discussion, amongst the young people, about the impact that this information and knowledge had on their own subsequent behaviour and the impact it had in the communities in which the drama productions took place. Although, young people spoke about the importance of the knowledge that they had learnt there seemed to be a disconnection to what they then did in practice and many young people continued with the same behaviour. This is not surprisingly as interventions which aim to bring about behaviour change through education are unlikely to succeed if they do not also focus upon changing the situations in which people live as multidimensional issues require multi-dimensional responses (Naidoo \& Wills 2009).

Young people, however, did speak about how taking part in the NGOs activities had resulted in them being listened to by others including those in their community who may not have listened to them previously:

'Think about how I used to live on street, no one used to listen to me, now people come very far to listen to me at events....they say listen to what he has said'.

This was also a theme which was taken up by the facilitators who discussed how the activities gave:

'a platform to the guys on the street.....big stakeholders, important people here are watching them.... guys from the street do plays about how they live and people in charge get to see'.

Another facilitator discussed how the activities brought about a sense of community and friendship, and how it mitigated some of the negative impacts of being on the street by instilling a sense of pride in the young people that they had something important to say and that what they said was valuable:

'It gives them a sense of belonging to a community; it allows them to dream again because being on the street is not a place to be..... lots of challenges and risk.......you feel neglected ....X gives them a sense they are still valuable.......gives them voices'. 
Young people spoke about the positive reactions from other people to their performances which they said helped to raise their self-esteem and strengthen their sense of self:

'Feels good when doing it [performing] and people say this boy is great......first time I danced people clapped made me feel that I could do anything'.

'Some children don't use their talent because no-one to push them.........they help you to discover your talents....helps you to know you are talented.....you are not just a street child, you have talent, and you can do it'.

Another young person spoke about how his involvement with the NGO was viewed positively by his community, peers and family and how it could lead to improved relationships:

'I have become popular through my performances, people like me now, when you leave your home in bad feelings they think you are bad.......they then hear good things about you at home, about what you are doing with $\mathrm{X}$, easy to forgive you then when they hear good things'.

However, whilst the young people reported many benefits from taking part in the NGOs activities, for example empowerment in relation to self-worth [power within to coin Rowlands (1995) and Mayoux and Johnson (2007)], it was not always clear what the impact was, for example on their day to day lives, of their collective voices being heard by stakeholders. Little evidence was offered of any significant change to the young people's lives and yet the rhetoric of participation and empowerment was used regularly, by everybody, to illustrate the importance of the activities and the importance of the young people's collective voices [power with] being heard. The concept of empowerment, therefore, as conceptualised in this situation did not appear to challenge the status quo nor the situation that the children were in and empowerment and participation were often limited to 'performance' with collective voices being heard and the children then returning to the street, ready to perform and be heard again when needed. This invited participation (Cornwall 2002; 2003) meant that 'empowerment' and 'participation' tended to be nonpolitical and maintained the status quo under a veneer of empowerment and of 'being heard' (Chambers \& Pettit 2004). 
Emphasising the political nature of empowerment and participation can be problematic for NGOs and trying to challenge the norms and values of institutions and the status quo can mean that they may be seen as 'trouble makers' who are not providing 'quality services to street children' if they are seen to challenge or encourage children to challenge hegemonic discourses which stakeholders and donors support. This was a point taken up by a donor who spoke about how 'they had been concerned that [the NGO] had organised a protest march to a conference (about street children) with street children and had put the children at risk because they had marched down a busy road'. Speaking to the NGO about this it was evident that this had been raised with them and that they had become more careful about 'upsetting the apple cart' and it was stated that they 'were conscious that some of their ways of doing were not seen as professional by some of the funders and that this in many ways impacts on what we do'. This tended to constrain some of their activities which were of a more political nature and instead the NGO concentrated on 'making sure the voices of children are heard through [collective] performance which always goes down well with funders'. This is problematic in that not being able to directly challenge the way that 'street-children' are positioned or treated, for example informal power or power over, can mean that change is difficult to bring about because values, norms and discourses about the position of streetchildren and structural inequality may not be systematically engaged with. Whilst performances may focus to some degree on some of the issues, reasons for why the children were on the street were not followed up and general inequality not highlighted within these performances. However, as stated earlier there is a tension here as political empowerment and participation of children and young people, by directly challenging inequality, could put them at risk especially in contexts which are not sympathetic towards them or not sympathetic to political protest. This tension may reflect why many development agencies focus their attention on 'giving children a voice' in relation to service delivery for example rather than empowering children politically to challenge the status quo and participate in a political dialogue. All this can, therefore, can result in 'thin agency' (Klocker 2007) and both children and NGOs can be constrained by contexts which restrict their agency including global discourses about what 'good' development looks like and what services will be funded. This 'power over', (exercised by adults over children; international development agencies and governments over grassroots agencies) therefore, can limit 'power with' and 'power to' and an understanding of how existing 'power relations' structure how empowerment takes place and is realised is needed by all concerned. 


\section{Change at an Individual Level and the Psychologising of Social Problems}

The idea of 'change' was apparent in all of the narratives including the young people and the facilitators as well as practitioners and donors. This change, however, tended to focus upon individual behavioural change as well as individual psychological change and the idea of becoming 'responsible citizens' or 'becoming perfect' was raised a number of times by the young people.

'My mind I can change, I can become someone.....X lived on street and he came here ....look at him now.......I look up to him and $\mathrm{Y}$ as well..........can be someone like them and earn a living......move off the street like them....I can change.....I can become perfect'.

'It helps us change our mind psychologically, become responsible citizens and start to do things responsibly'.

This was also a theme taken up by the facilitators and donors:

' $\mathrm{X}$ helped me to do something... it helped me to change..... in my compound I was doing bad things....I started to do acrobatics and stopped doing bad things..... now acting..... doing things to stop myself doing bad things' (facilitator).

'One of the key factors is about how much taking part in X's activities change the behaviour of the children....' (donor).

The idea of personal change was in this context, therefore, a hegemonic discourse, which occurred, almost in all of the interviews individualising the issues which faced the young people as being something that they could change if they themselves changed. Structural inequalities and poverty (political concerns) were barely mentioned as the root cause of why the children were on the street although one practitioner did briefly talk about 'push' and 'pull' factors and one young person spoke about 'how life was unfair' but these discussions then continued on to discuss how changing individual behaviour would potentially change individual situations. This type of discourse could be viewed in a number of ways and could 
be understood as a strategy of hope in the face of chronic poverty and an unfair system which seemed impossible to change. Individual transformation and the psychologising of social problems as individual problems of behaviour may, therefore, be seen as more amenable to change than more radical social change or transformation.

This, however, can result in a depoliticised narrative which emphasises a technical response to individual behavioural change and tended, unconsciously, to position the young people as somehow being responsible for their situation because of their behaviour (Berckmans et al 2012; Thomas de Benitez 2011). Moreover, what was also apparent from the young people's narratives, in this particular context, was that they spoke about themselves in this way too. Southern \& Pralhad (2003) found something similar in their research in Nepal where some of the 'street children' characterised themselves as 'delinquents' and blamed themselves for the situation that they found themselves in. Thus discourses and regimes of representation which position certain children in a particular way may not only have influenced how children who lived on the street were viewed and engaged with but also influenced how this group of children constructed their identity and experienced their identity in particular contexts (Said 1978; Freire 1985; Spivak 1988; Morgan \& Sengedorj 2015). Rowland's (1995) discussion of 'power over' is relevant here and how those who are oppressed can often internalise how they are represented by the more powerful. An over-emphasis on psychology, psycho-social interventions and behaviour change, therefore, can pathologize young people, disempowering them in the process, ensuring that they focus on how they are to blame for their situation as opposed to how structural inequalities (the political) limit their opportunities and life chances. Change is, therefore, directed at the individual (power within) as opposed to society (power over); and empowerment becomes about individual transformational as opposed to societal transformational.

\section{Facilitators, Young People and Aspirations for the Future: Capacity Building}

The young people who lived on the street expressed concern about some of the facilitators. This included facilitators not turning up for the workshops and it was stressed, by the young people, that regular sessions as well as enough rehearsal time for performances was needed.

'The facilitators sometimes don't turn up and you are waiting for them'. 
'Some children forgot what they learnt because don't come often enough.... have to remind yourself what you did last time as so long ago'.

Young people also spoke about issues to do with the behaviour of some of the facilitators and reported facilitators sometimes getting angry at them and shouting at them:

'In the workshops you are creating a piece and the facilitators will get upset.... should calm down.....it is not nice'.

The behaviour of their peers was also a sense of stress for some of the young people and they discussed how:

'when we perform and make a mistake others will become frustrated and laugh at you'.

This was upsetting and was a sense of deep embarrassment for many of the young people who felt unsupported by some of the facilitators who, they felt, did not deal with this behaviour.

However, facilitators also spoke about the difficulties of their work and this has been echoed in other research (Bademci 2012). Facilitators stated that very often the young people would come to sessions 'straight from the street', that they 'were high' or 'drunk' and sometimes 'do not get what I am saying' or were 'doing their own thing, not doing what they were supposed to... being lazy'. Many of the facilitators highlighted that they needed more training to work with vulnerable young people as well as more support and supervision. Some of the facilitators spoke about how it can be difficult to go to a centre:

'where you have never worked before and there are 20 children there who don't know you and you don't know them....important that you have full support from the centre'.

This support from the centre and from the NGO was seen as important because: 
'the people running the workshops [the facilitators] are sometimes more vulnerable than the children'.

This was also echoed by one of the 'carers' who worked at one of the drop in centres who stated that some of the facilitators were 'more problematic than the children'. Whilst a worker in another centre stated that:

'Facilitators should know they are approaching people from different backgrounds....not brought up like them.....expect to be treated in a particular way but facilitators don't always do this'.

Hence the facilitators who lived in the slum areas were often as vulnerable as the children who lived on the street and Butler (2009: 16) has suggested that 'those on the street are virtually indistinguishable from other youngsters from the same communities'. Capacity building, therefore, of local people and communities whilst key needs to be underpinned by appropriate supervision, training and support. Expecting vulnerable facilitators to cope effectively with challenging behaviour from vulnerable young people without adequate support and training was often asking too much.

What was apparent from many of the young people narratives was that being involved with the NGO had inspired them to do something with their life and many spoke about becoming an artist or a facilitator in the future. This they felt would enable them to move off the street and 'earn money' from what they were doing and what they enjoyed doing. However, this in itself was problematic and although the young people spoke about these aspirations there were very few examples of young people who had actually moved off the street or who had become facilitators.

Moreover, in the discussions with the facilitators talk about 'earning a living' came up regularly and the voluntary name of the facilitators work was emphasised by all:

'Although I love X.... rather spend my time here....... what I get out of it does not support my life. Need to employ facilitators properly and ensure enough paid work'. 
'Feel like stopping..... getting pressure from family.......they say nothing I am doing here. I need to make money from activity'.

There was, therefore, an unrealistic relationship between the aspirations of the young people and the reality of the facilitators work, and all of the facilitators spoke about the need for the NGO to provide more paid work and more opportunities including training opportunities and sponsorship for study. Career progression was mentioned a number of times for both the facilitators and for the young people. Facilitators stated that the latter could become facilitators and then the facilitators could become promoted or work within the office. It was felt that not enough was being done here:

'Feels like I am not doing anything........they should train people you know to do things.......not people you don't know'.

'Use your workforce.......create roles for them'.

The idea, therefore, of capacity building of the local community through their involvement with the NGO was not realised and opportunities for 'street children' to become facilitators or for facilitators to become paid workers were slim. This can be related back to Sen's (2001) focus on capabilities and opportunities and the idea that capacity building and empowerment must go beyond just focusing on developing skills and knowledge to ensure that 'real' opportunities to reach potentials are available including employment and study opportunities. Furthermore, the voluntary nature of the facilitators work often meant that if paid work did arise they had to prioritise this over their work with the NGO and this was the reason given for not turning up for sessions and the impact this then had, in turn, on the services provided to 'street children'.

\section{Conclusions}

There was real affection for the NGO from all of the young people as well as the facilitators and it was evident that the NGO were passionate and committed about what they did. There were many positive aspects to their work and this paper, therefore, is not meant as a critique of the work of this particular NGO. Instead, this paper is a more general critique of a depoliticised system which often results in concepts like capacity building, empowerment and 
participation being used in an unreflective and narrow way by practitioners, stakeholders and donors. Furthermore, an over-emphasis on the individual 'psychologised' child or young person as the unit of change feeds into this depoliticised way of thinking about social action and can result in structural barriers to change not being adequately engaged with. Whilst, it may be the case that culturally appropriate psychological interventions may be required for children who live and work on the street, an over-emphasis on psychology as the major driver for change is problematic and there is a need to balance psychological interventions with politicised services for children who live and work on the street so that inequality is tackled at structural and institutional levels. 'Empowering' children and young people [power within, power to and power with] without acting upon structural inequalities [power over] is counter-productive and real change can only occur if structural barriers to equality are effectively engaged with and empowerment represents something more than just having your voice heard.

Reflection, therefore, on the big questions about development is needed by development agencies and NGOs (Thomas 1999). This should include critical reflection on the social and political intent of participation initiatives including empowerment strategies as well as how far capacity building interventions really bring about freedom and increase capabilities in the way that Sen envisaged. Building people's skills up when there is little opportunity to improve their situation through job prospects seems problematic, in that hopes are raised with little chance of realisation. There is a need, therefore, for development agencies and NGOs to reflect upon why their services are needed and how these services will lead to emancipatory participation, empowerment and capacity building. If this is not engaged with what can result is an institutional landscape which reflects the dominant values of neoliberalism with empowerment and participation meaning choice and voice as opposed to a way to bring about liberalising change.

Reflection on how existing 'power relations' structure how empowerment takes place and is realised is thus needed. This includes reflection upon the unequal power relationships that exist between small scale grassroots NGOs, governments and donors. The position of grassroots NGOs can be problematic especially in relation to funding which can restrict their ability to critique government and donor policies leading to NGOs exercising thin agency. 
My anxiety about not identifying the NGO in this paper and my reference to sub-Saharan Africa instead of the country or area evidences the unequal power relationships that exists between small scale grassroots NGOs and donors. Reflection by donors and international agencies is, thus, needed on how the position of the grassroots NGO can be strengthened to enable them to challenge what is occurring on the ground as well as challenge more dominate discourses about the position of 'street children' and more effectively advocate on behalf and with vulnerable young people

7543 words 


\section{$\underline{\text { References }}$}

Arnstein, S. (1969). A Ladder of Citizen Participation, Journal of the American Planning Association, vol. Vol. 35, no. No. 4, pp. 216-224

Bademci, O.H., \& Figen, F., E. (2013)., Working with Street Boys: Importance of Creating a Socially Safe Environment through Social Partnership, and Collaboration through Peer-based Interaction. Child Care in Practice. Volume 19, Issue 2. 162-180

Bademci, O.H., (2012). 'Working with vulnerable children': Listening to the views of the service providers working with street children in Istanbul. Children and Youth Services Review, 34 4, 725-734.

Balen, R., Blyth, E., Calabretto, H., Fraser C., Horrocks, C., \& Manby, M. (2006). Involving children in health and social research: 'Human becomings' or 'active beings'? Childhood, 13(1), 29-48.

Beazley, H \& Ennew, J., (2006). Participatory Methods and Approaches: Tackling the Two Tyrannies in Desai, V \& Potter, R.B., (Eds). Doing Development Research. London: Sage.

Berckmans , I., Losantos Velasco, M, Pinto Tapia, B \& Loots, G., (2012). A systematic review: A quest for effective interventions for children and adolescents in street situation. Children and Youth Services Review, vol. 34, issue 7, 1259-1272

Bleazley, H., (2003) Voices from the Margins: Street Children's Subcultures in Indonesia. Children's Geographies, Vol. 1, No. 2, 181-200

Bordonaro, L.I., (2012). Agency does not mean freedom: Cape Verdean street children and the politics of children's agency. Children's Geographies, Vol 10, No4, 413-426

Boyden, J \& Ennew, J., (1997). Children in focus: a manual for participatory research with children. Stockholm: Radda Barnen.

Brown D, \& Korten D (1989). Understanding Voluntary Organizations: Guidelines for Donors, " Working Paper 258. Washington: World Bank, Country Economics Department

Butler, U.M., (2009). Freedom, Revolt and Citizenship: Three pillars of identity for youngsters living on the streets of Rio de Janeiro. Childhood, 16 (1), 11-29

Chambers, R., (2005). Ideas for Development. London: EarthScan

Chambers, R., (1997)., Whose Reality Counts? Putting the First Last, London: Intermediate Technology Publications.

Chambers, R. and J. Pettit (2004). Shifting Power to Make a Difference. Inclusive Aid: Changing Power and Relationships in International Development. L. Groves and R. Hinton. London: Earthscan.

Christensen, P and James, A. (2008) Research with Children: Perspectives and Practices (2nd edn). London: Falmer. 
Coates, B., and David, R., (2002). Learning for Change: The art of assessing the impact of advocacy work. Development in Practice, Volume 12 Number 3 \& 4. 530-541

Cooke, B., (2004). The managing of the Third World. Organization. 11, 5, 603-629

Cooke, B., and Kothari, U., (2000), Participation: The New Tyranny? London: Zed Books

Cornwall, A \& Brock, K., (2005). What do Buzzwords do for Development Policy? A critical look at 'participation', empowerment' and 'poverty reduction'. Third World Quarterly, Vol 26, No \&, 1043-1060

Cornwall, A., (2003). Beneficiary, consumer, citizen: Perspectives on Participation for Poverty Reduction. SIDA Studies no 2, Stockholm: Swedish International Development Cooperation Agency

Cornwall, A., (2002). Making spaces, changing places: situating participation in development. IDS Working Paper 170, Brighton: Institute of Development Studies

de Carrizosa, S \& Poertner, J., 1992. Latin American street children: problem, programmes and critique. International Social Work, 35: 405-413.

DFID, (2008). DFID research strategy 2008-2013 Working Paper Series: Capacity Building http://r4d.dfid.gov.uk/PDF/Outputs/Consultation/ResearchStrategyWorkingPaperfinal_capaci ty P1.pdf (accessed 2nd February 2016)

Dybicz, P., (2005). Interventions for street children: An analysis of current best practices International Social Work, 48, 763-771

Ennew, J., (2000). Street and Working Children: A guide to planning. London: Save the Children

Ennew, J., (1995). Outside childhood: street children's rights. In B. Franklin (ed). The Handbook of Children's Rights: Comparative Policy and Practice. London: Routledge. 308-403

Ennew, J (1986). "Children of the Street." New Internationalist 164(October): 10-11.

Fals-Borda, O., \& Rahman, M. A. (1991). Action and Knowledge: Breaking the Monopoly with Participatory Action-Research (1st Ed.). New York: Apex Press.

Freire, P., (1985). The Politics of Education: Culture, Power and Liberation. London: Macmillan

Freire, P. (1970). Pedagogy of the oppressed, New York : Continuum

Hardman, C. (1973). 'Can There Be Anthropology of Children?' Journal of the Anthropological Society of Oxford 4, 85-99. Reprinted in Childhood 8, 501-17 (2001).

Harris, M.S., Johnson, K., Young, L., \& Edwards J., (2011). Community reinsertion success of street children programs in Brazil and Peru. Children and Youth Services Review, $3723-731$ 
Holloway, S., \& Valentine, G., (eds) (2000). Children's geographies and the new social studies of childhood in Children's geographies: playing, living, learning. London: Routledge.

James, A. and Prout, A. (eds) (1990) Constructing and Reconstructing Childhood, London: Falmer Press

James, A., Jenks, C., \& Prout A., (1998). Theorizing Childhood. Cambridge: Polity Press.

Johnson, H. and Wilson, G., (2000) 'Biting the Bullet: Civil Society, Social Learning and the Transformation of Local Governance', pp1891-1906, World Development, Vol. 28, No.11

Kaime-Atterhög, W., Lindmark, G., Persson, L.A., \& Ahlberg, B.M., (2007). Burning "centre bolt": Experiences of sexually transmitted infections and health care seeking behaviour described by street boys in Urban Kenya. Children and Youth Services Review, $29 \quad 600-717$

Klocker, N. (2007) An example of thin agency: child domestic workers in Tanzania. In: R. Panelli, S. Punch and E. Robson, eds. Global Perspectives on Rural Childhood and Youth: Young Rural Lives. London: Routledge, pp.81-148.

Laverack, G. and Wallerstein, N. (2001) Measuring community empowerment: a fresh look at organizational domains. Health Promotional International , 16, 179-185

Lusk, M.W. (1989). Street children programs in Latin America. Journal of Sociology and Social Welfare 16:55-77

Mayoux, L. and Johnson, H (2007), Investigation as Empowerment: Using Participatory Methods" in Thomas, A and Mohan, G (eds.) Research skills for policy and development: how to find out fast, Sage Publications Ltd.

Morgan, J \& Sengedorj, T. (2015). 'If you were the researcher what would you research?': Understanding children's perspectives on research in Mongolia and Zambia. Research and Method in Education. 38 (2) 200-218

Mosedale, S., (2014). Women's Empowerment as a Development Goal: Taking a Feminist Standpoint. Journal of International Development. 26, 1115-1125

Mosse, D., (1994). Authority, gender and knowledge: theoretical reflections on the practice of participatory rural appraisal. Development and Change, 25: 497-526

Morrow, V. (2009). The Ethics of Social Research with Children and Families in Young Lives: Practical Experiences. Working Paper no 53. Available at: $\underline{\text { www.younglives.org.uk }}$

Naidoo, J. \& Wills, J. (2009), Foundations for health promotion. 3rd ed. Edinburgh: Baillière Tindall Elsevier.

Oxaal Z, \& Baden S. (1997). Gender and Empowerment: Definitions, Approaches and Implications for Policy. Bridge Report No 40 Brighton, Sussex: IDS. 
Panter-Brick, C., (2002), Street children, human rights and public health: A critique and future directions. Annual Review of Anthropology. Vol. 31: 147-171

Parfitt, T., (2004). The ambiguity of participation: a qualified defence of participatory development. Third World Quarterly, Vol 25, No 3, 537-556

Percy-Smith, B \& Thomas, N (2010). A handbook of children and young people's participation: perspectives from theory and practice. London: Routledge

Petitt, J., (2012). Empowerment and Participation: bridging the gap between understanding and practice. Institute of Development Studies. Available at: http://www.un.org/esa/socdev/egms/docs/2012/JethroPettit.pdf

Rizzini, I \& Lusk, M.W., (1995) Children in the Streets: Latin America's Lost Generation. Children and Youth Services Review, v17 n3. 391-400

Rowlands, J., (1995). Empowerment Examined. Development in Practice Vol. 5, No. 2 101-107

Said, E. (1978). Orientalism. London: Routledge

Salo, J., (2009). Educating the drop-outs; the case of street children in Maputo City, Mozambique. MA Dissertation: University of Tampere. Available at: https://tampub.uta.fi/bitstream/handle/10024/80991/gradu03845.pdf?sequence=1 (accessed $24^{\text {th }}$ February 2016)

Sen, A., (2001). Development as freedom. Oxford New York: Oxford University Press

Sondhi-Garg, P., (2004). Street Children: Lives of Valor and Vulnerability. New Delhi: Reference Press

Silverman, D. (2006). Interpreting Qualitative Data: Methods for Analysing Talk, Text and Interaction. 3rd Edition. London: Sage

Southon, J \& Pralhad, D., (2003). A life without basic services: Street children say. Save the Children UK/Nepal

Spivak, G. (1988) Can the subaltern speak? in G Nelson \& L Grossberg (eds) Marxism and Interpretation of Culture. Chicago, IL: University of Illinois Press. pp271-313

Thomas de Benitez, S., (2011). State of the World's Street Children: Research. London: Consortium for Street Children

Thomas de Benitez, S., (2003). Reactive, Protective and Rights-Based Approaches in Work with Homeless Street Youth. Children, Youth and Environments, Vol 13, Issue 1, Spring

Thomas, A., (1999). What makes good development management? Development in Practice, 9, $(1 \& 2)$ 9-17 
Tjahjorini Sr., Slamet, M., Asngari, P.S., \& Susanto, D.D., (2005) Perception of street children toward social guidance in open house program at Bandung city. Jurnal Penyuluhan 1(1): 21-32.

United Nations (UN) (1989) United Nations Convention on the Rights of the Child. Geneva: UN.

Vakil, A.C., (1997). Confronting the Classification Problem: Toward a Taxonomy of NGOs" World Development, Vol. 25, No. 12, 2057-2070.

Wallace, T, and Mordaunt, J (2007) 'When is the price too high? Gaining funding from institutional sources', In: Mordaunt, J and Paton, R (eds) Thoughtful Fundraising. Abingdon: Routledge.

White, S.C. \& Choudhury, S, A., (2007). The Politics of Child Participation in International Development: The Dilemma of Agency. The European Journal of Development Research, Vol 19, No 4. 529-550

White, S.C., (2007). Children's Rights and the Imagination of Community in Bangladesh. Childhood vol. 14 no. 4 . 505-520

World Health Organisation (2000). Working with Street Children. Available at http://www.who.int/substance_abuse/activities/street_children/en/ Accessed 13/10/14 